\title{
A PRELIMINARY REPORT
}

G Fred Brindle. B A., M D , C M , R G B. GilBert, F.r C P (C), F F A.r C.S., and R A. Millar, M D, F F a R C S *

Pharmacological studifs ( 1 ) and early clinical reports $(2,3,4)$ have attributed to trifluorobromchlorethane $\left(\mathrm{CF}_{3} \mathrm{CHClBr}\right.$, Fluothane) a combination of pharmacological actions unique among the volatıle/ anaesthetic agents. Ready controllability, rapıd postoperative elimmation, adequate potency, a reversible hypotensive action and absence of explosive properties are obvious advantages in the anaesthetic management of the neurosurgical patient

This report is concerned with 10z...administrations of Fluothane for minor and major neurosurgical procedures The results of liver function tests performed on 31 patients will be presented, certan clinical observations and the impressions derived therefrom will be assessed and discussed, and an evaluation will be attempted of electrocardiographic records obtamed on 31 occasions in 29 patients.

\section{Clinical Material}

The distribution of the patients by age and sex and a broad classification of the operations performed, including the range and average duration, are shown in Tables I.and II.

TABLE I

\begin{tabular}{|c|c|c|c|c|c|c|c|c|c|c|}
\hline & \multicolumn{9}{|c|}{ Age } & \multirow[b]{2}{*}{ Total } \\
\hline & $0-2$ & $3-10$ & $11-20$ & $21-30$ & $31-40$ & $41-50$ & $51-60$ & $61-70$ & $71-80$ & \\
\hline Male & 6 & 6 & 2 & 9 & 16 & 7 & 5 & 2 & 1 & 54 \\
\hline Female & 2 & 3 & 4 & 4 & 6 & 8 & 5 & 2 & - & 34 \\
\hline Total & 8 & 9 & 6 & 13 & 22 & 15 & 10 & 4 & 1 & 88 \\
\hline
\end{tabular}

TABLE II

\begin{tabular}{lcc}
\hline \multicolumn{1}{c}{ Operation } & No & Average duration and range (min) \\
\hline Superficial, cranial and extracranial & 20 & $162(80-360)$ \\
Intracranial & 35 & $264(60-500)$ \\
Spinal & 23 & $260(60-570)$ \\
Radiological investigations & 30 & $101(60-240)$ \\
Total & 108 & 199 \\
\hline
\end{tabular}

"Department of Anaesthesia, Montreal Neurological Instrtute and McGill University, Montreal, Quebec 


\section{METHOD}

In most instances premedication was atropine alone, variations in premedication are shown below.

\begin{tabular}{lc}
\multicolumn{1}{c}{ Premedication } & No of patients \\
Atropine only & 79 \\
Atropine and Demerol & 6 \\
Atropine and barbiturate & 3 \\
Atropine and codeine & 5 \\
Atropine and Benadryl & 1 \\
Atropine and Phenergan & 1 \\
Largactil, Phenergan, Demerol & 8 \\
Nil & $\mathbf{5}$ \\
Total & $\mathbf{1 0 8}$
\end{tabular}

On 85 occasions, which included all adults, anaesthesia was induced with thiopental in amounts not exceeding $500 \mathrm{mg}$., followed by succinylcholne chlonde up to $50 \mathrm{mg}$; laryngeal intubation was preceded by topical application of 10 per cent cocaine or 4 per cent lidocaine. Anaesthesia was induced with nitrous oxide-oxygen-Fluothane on 21 occasions in children and infants; or 2 infants cyclopropane was used.

For 78 procedures a non-rebreathing technique was employed to administer nitrous oxide-oxygen-Fluothane, using the Stephen-Slater valve or the Fink modification. The oxygen percentage in the mixture was mantamed above 30 . The Marrett head of the Aur-Med apparatus, modified for admunstration of high flows of nitrous oxide oxygen, was convenient and proved very satsfactory in practice. Fluothane was administered from the "Trlene" vaporizer filled to the 2 fluid ounce level and mantaned as close to that level as possible thereafter. The concentrations of Fluothane delivered (volumes per cent), using a total flow rate of 10 litres per minute, are: 0.5 per cent at the first mark on the vaporizer, 1.0 per cent at the second, and 15 per cent at the third (5). A 1 per cent concentration of Fluothane was almost invariably employed for maintenance of anaesthesia. Concentrations above 2 per cent (reached midway between mark 3 and "on") were rarely used.

For thirty radiological investigations under anaesthesia an unmodified Marrett head was utilized; high flow rates of gases were administered in a semi-closed system with a fully open expuratory valve.

Electrocardrographic tracings were obtained with a Sanborn Viso-Cardiette during thirty-one major neurosurgical procedures. With two exceptons local anaesthetic (Nupercaine. 1/1500) with added adrenaline (1/250,000 of free base) was injected, by the surgeon, in amounts close to $125 \mathrm{ml}$. Blood samples were withdrawn from three patients about ten minutes after the injection of local anaesthetc with added adrenaline Plasma adrenaline and noradrenaline were estimated by a modification (6) of the method of Von Euler and Floding (7).

Four tests of liver function were performed on thirty-one patients. About one hour prior to operation blood was withdrawn for determination of serum bilirubin and prothrombin time, and for the cephalin-cholesterol flocculation test; brom- 
sulphalein was injected ( $5 \mathrm{mg} . / \mathrm{kg}$.) and 45 minutes later blood was withdraum in order to determine bromsulphalein excretion. The tests were repeated on the first, the third or fourth and finally the seventh day after the operation.

\section{Results}

\section{Liver Function Tests}

Retention of bromsulphalein occurred preoperatively in four seriously ill patients, in whom the postoperative findıngs are shown in Table III. Further increases

TABLE III

Increased Preoperative Bromsulphalein Retention

\begin{tabular}{|c|c|c|c|c|c|c|}
\hline \multirow[b]{2}{*}{ Patient } & \multirow[b]{2}{*}{ Operation } & \multirow{2}{*}{$\begin{array}{c}\text { Duration } \\
\text { (hrs) (min) }\end{array}$} & \multirow[b]{2}{*}{$\begin{array}{c}\text { Preop. } \\
(\%)\end{array}$} & \multicolumn{3}{|c|}{ Number of days after operation } \\
\hline & & & & 1 & $\begin{array}{c}3 \\
(\%)\end{array}$ & 7 \\
\hline 1 & Incısion and repacking & 30 & 50 & 40 & - & 40 \\
\hline 2 & Hypophysectomy & 730 & 50 & 30 & 225 & 22 \\
\hline 3 & Craniotomy & 320 & 10 & 24 & 20 & 22 \\
\hline \multirow[t]{2}{*}{4} & Hypophysectomy & 630 & 13 & 25 & - & 8 \\
\hline & AVERAGE & 55 & 308 & 298 & 213 & 23 \\
\hline
\end{tabular}

TABLE IV

Normal Postoperative Bromsulphalein Retention

\begin{tabular}{|c|c|c|c|c|c|c|}
\hline \multirow[b]{2}{*}{ Patient } & \multirow[b]{2}{*}{ Operation } & \multirow{2}{*}{$\begin{array}{c}\text { Duration } \\
(\mathrm{hrs})(\mathrm{m} 1 \mathrm{n})\end{array}$} & \multirow[b]{2}{*}{$\begin{array}{c}\text { Preop } \\
(\%)\end{array}$} & \multicolumn{3}{|c|}{ Number of days after operation } \\
\hline & & & & 1 & $\begin{array}{c}3 \\
(\%)\end{array}$ & 7 \\
\hline 1 & Cervical laminectomy & 340 & 2 & 2 & 2 & 3 \\
\hline 2 & Lumbar discoldectomy & 310 & 35 & 5 & 5 & 38 \\
\hline 3 & Carotıd ang1ogram & 140 & 2 & 3 & 5 & 2 \\
\hline 4 & Lumbar discoidectomy & 6.0 & 2 & 18 & 2 & 2 \\
\hline 5 & Spinal fusion & 440 & 2 & 2 & 2 & - \\
\hline 6 & Cervical laminectomy & 80 & 2 & 2 & 5 & 2 \\
\hline 7 & Reparr of CSF leak & 30 & 3 & 15. & - & 一 \\
\hline 8 & Cervical laminectomy & 515 & 2 & 2 & 2 & 1 \\
\hline 9 & Cranotomy & 610 & 2 & 2 & 2 & 5 \\
\hline 10 & Frontal débridement & 20 & 2 & 2 & 2 & 1 \\
\hline 11 & Cramotomy & 445 & 2 & 6 & 2 & 2 \\
\hline 12 & Lumbar discoidectomy & 50 & 2 & 3 & 2 & 2 \\
\hline 13 & Lumbar discoldectorny & 330 & 1 & 2 & 2 & 3 \\
\hline 14 & Re-opening craniotomy & 830 & 4 & 6 & 5 & 2 \\
\hline 15 & Lumbar discoldectomy & 415 & 1 & 1 & 1 & 1 \\
\hline 16 & Spinal fusion & 410 & 1 & 1 & 2 & 2 \\
\hline 17 & Craniotomy & 445 & 6 & 8 & 6 & 5 \\
\hline 18 & Lumbar discordectomy & 60 & 2 & 8 & 2 & 2 \\
\hline \multirow[t]{2}{*}{19} & Lumbar discoldectomy & 40 & 2 & 3 & 3 & 1 \\
\hline & AVERAGE & 439 & 23 & 32 & 29 & 23 \\
\hline
\end{tabular}




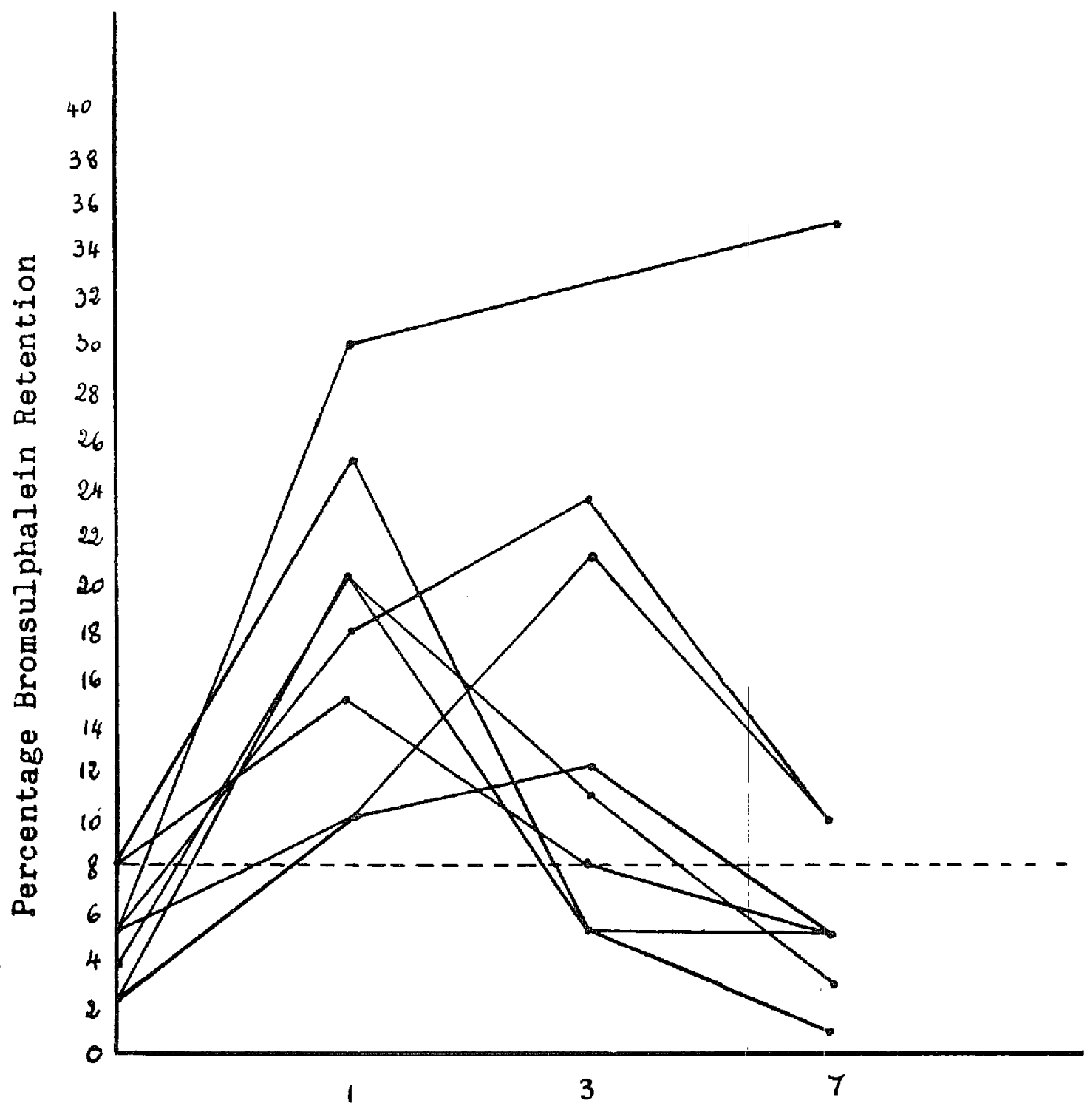

Da y s Postoperative

FIGURE 1. Increased postoperative bromsulphalein retention.

occurred in two of these patients. Pre- and postoperative values below 8 per cent, considered to be within normal limits, were obtained in nineteen patients, as shown in Table IV. Estimations of total serum bilirubin were within normal limits (below $1 \mathrm{mg}$. per cent) in all cases with a single possible exception: one patient showed a preoperative value of $0.8 \mathrm{mg}$. per cent rising to 1.3 and $1.0 \mathrm{mg}$. per cent on the first and third postoperative days, returning to $0.5 \mathrm{mg}$. per cent by the seventh day. In this patient bromsulphalein retention, which increased from 2 per cent preoperatively to 20 per cent and 11 per cent on the first and third postoperative days respectively, returned to a normal 3 per cent on the seventh day. The cephalin-cholesterol flocculation test was within normal limits ("one plus" or "negative") in all patients at all times. According to the data 
TABLE V

InCREASEI POSTOPERATIVE Bromsulphalein Retention

\begin{tabular}{|c|c|c|c|c|c|c|}
\hline \multirow[b]{2}{*}{ Patient } & \multirow[b]{2}{*}{ Operation } & \multirow{2}{*}{$\begin{array}{c}\text { Duration } \\
(\text { hrs })(\min )\end{array}$} & \multirow[b]{2}{*}{$\begin{array}{c}\text { Preop } \\
(\%)\end{array}$} & \multicolumn{3}{|c|}{ Number of days after operation } \\
\hline & & & & 1 & $\begin{array}{c}3 \\
(\%)\end{array}$ & 7 \\
\hline 1 & Cervical discoidectomy & 340 & 2 & 10 & 12 & 5 \\
\hline 2 & Lumbar discoidec tomy & 320 & 5 & 30 & - & 35 \\
\hline 3 & Cranıotomy & 70 & 8 & 15 & 8 & 5 \\
\hline 4 & Craniotomy & 330 & 5 & 10 & 21 & 10 \\
\hline 5 & Craniotomy & 60 & 8 & 25 & 5 & 5 \\
\hline 6 & Cervical laminectomy & 930 & 3 & 20 & 5 & 1 \\
\hline 7 & Craniotomy & 410 & 5 & 18 & 235 & 10 \\
\hline 8 & Craniotomy & 505 & 2 & 20 & 11 & 3 \\
\hline & AVERAGE & 527 & 47 & 185 & 122 & 92 \\
\hline
\end{tabular}

obtaned, no significant increases in prothrombin time occurred. Increased retention of bromsulphalem after Fluothane anaesthesia was found in eight patients who showed normal preoperatuve values (Table V, Fig. 1). If the two patients who showed increased bromsulphalein retention preoperatively are included, the incidence of abnormal postoperative findings which can be directly related to Fluothane anaesthesia in this series of thirty-one patients becomes 32 per cent; of these ten patients, six showed a maximal rise on the first postoperative day; in four patients the rise was maximal on the third postoperative day. By the seventh day normal values were restored in six and nearly normal values in two patients In two cases the values on the seventh postoperative day were abnormal, although in one of these the preoperative value had also been increased.

\section{Clinical Observations}

A generally favourable impression of Fluothane has been gained as a result of 108 administrations to 88 neurosurgical patients.

In 21 inductions with nitrous oxıde-oxygen, transition to Fluathane-oxygen was smooth, without irritation or mucous secretion in the respiratory tract. After induction with thiopental and succinylcholine, Fluothane anaesthesia can be establıshed quickly and uneventfully

Eventful administrations

Difficulty in inducing anaesthesia
Anaesthesia adequate, vasopressors required

Circulatory depression, anaesthesta inadequate, vasopressors required

Steady state of anaesthesia disturbed by surgical stımul

Hypotension and respiratory depression

Airway obstruction

Auricular fibrillation

Total

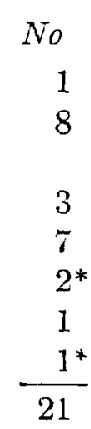

*Two patients requinng vasopressor therapy are also uncluded under the headings "respiratory depression" and "auricular fibrillation" 
Those Fluothane administrations which require further comment are listed on the preceding page.

Difficulty was encountered with a 4-month-old baby: after a cyclopropane induction, endotracheal Fluothane-oxygen was started, but a steady state of anaesthesia could not be achieved. The baby was satisfactorily anaesthetized with ether.

In five adults and one child, when anaesthesia had been carefully assessed and considered satisfactory, surgical stimulation subsequently induced coughing, straining or reflex movement. A 3-year-old child showed prolonged extensor spasms of the limbs although concentrations of Fluothane above 2 per cent were administered.

In this series hypotension has occurred frequently durıg Fluothane anaesthesia. Table VI lists the lowest and the highest systolic blood pressures observed. In 45 per cent of 101 administrations the lowest systolic blood pressure was at some time in the range $80-100 \mathrm{~mm}$. $\mathrm{Hg}$. Changes in heart rate have been less noteworthy (Table VII).

Table VIII gives the lowest and highest respiratory rates recorded during 68 administrations; tachypnoea was relatively frequent.

TABLE VI

Systolic Blood Pressures

(101 patients)

\begin{tabular}{lcccccc}
\hline Systolic B P & $<60$ & $61-80$ & $81-100$ & $101-120$ & $121-140$ & $>140$ \\
Lowest & 8 & 16 & 46 & 26 & 5 & - \\
Highest & - & - & 27 & 45 & 22 & 7 \\
\hline
\end{tabular}

TABLE VII

Heart Rates

(101 patients)

\begin{tabular}{lccccc}
\hline Heart rate & $<60$ & $61-80$ & $81-100$ & $101-120$ & 120 \\
Slowest & 7 & 42 & 41 & 14 & 4 \\
Fastest & - & 20 & 45 & 28 & 15 \\
\hline
\end{tabular}

TABLE VIII

RESPIRATORY RATES

(68 patients)

\begin{tabular}{lcccccc}
\hline Respiratory rate & $<10$ & $11-20$ & $21-30$ & $31-40$ & $41-50$ & $51-60$ \\
Slowest & 1 & 21 & 36 & 10 & 0 & 0 \\
Fastest & 0 & 4 & 36 & 24 & 2 & 2 \\
\hline
\end{tabular}

With Fluothane an adequate plane of surgical anaesthesia may not be maintained without concomitant hypotension. One example may be noted.

A 59-year-old female patient was anaesthetized and postured in the semi-recumbent position for sub-temporal exploration of the fifth cranial nerve. No local ansesthetic was employed. Durng the surgical approach anaesthesia appeared adequate, but systolic pressure was 75-85 
$\mathrm{mm} . \mathrm{Hg}$ Stimulation of the fifth nerve sroduced immediate coughing and straining, o restore a steady state of anaesthesia $250 \mathrm{mg}$ o- thiopental was given over the next five min 1 tes. The hypotension induced by Fluothane was not potentiated by thiopental in this patient, the blood pressure being maintained at $80-90 \mathrm{~mm}$. $\mathrm{Hg}$

In three patients vasopressor therapy was necessary to maintain with safety an adequate depth of anaesthesia. During a craniotomy the concentration of Fluothane was decreased because of sudden hypotension (to $80 \mathrm{~mm}$. $\mathrm{Hg}$ ); the patient responded by moving, and satisfactory conditions could only be restored by increasing the concentration of Fluothane and employing a continuous neosynephrine infusion Another patient developed hypotension (to $60 \mathrm{~mm} . \mathrm{Hg}$ ) when anaesthesia was deepened after a bout of coughing during lumbar discoidectomy; intravenous vasoxyl, $5 \mathrm{mg}$., followed by a neosynephrine infusion, permitted satisfactory operating conditions for the remaining hour of operation. Again, a hypertensive patuent undergoing lumbar discoidectomy required $20 \mathrm{mg}$. of vasoxyl and a contınuous neosynephrine infusion over a three-hour period.

Vasopressor therapy wels necessary in seven patients because of hypotensive states occurring in the course of satisfactory anaesthesia. In two of these patients blood loss may have been a contributing factor. Intravenous vasoxyl, $2-5 \mathrm{mg}$., has been found entirely satisfactory to counteract hypotension during Fluothane anaesthesia. Neosynephrme infusions $(20 \mathrm{mg} / 500 \mathrm{ml}$.) are equally effective and may be more convenent during prolonged operations.

In two patients with spinal cord lesions, extreme sensitivity to the hypotensive action of Fluothane was apparent. No such effect has been observed with ether anaestheșia.

A 25-year-old male patient with a spinal cord tumour at D4 level developed respiratory depression when the systolic pressure fell abruptly to $65 \mathrm{~mm} \mathrm{Hg}$ within a few minutes of startıng endotracheal Fluothane-oxygen anaesthesia A prompt response to $5 \mathrm{mg}$ of intravenous vasoxyl was abtanned, ether was substituted for Fluothane and a blood pressure of $100 \mathrm{~mm}$. could be maintamed whle ether was given On two subsequent occasions administration of Fluothane was resumed (concentration about 1 per cent), and blood pressure again became depressed to levels of 70 and $80 \mathrm{~mm} \mathrm{Hg}$ Similarly in a 22-year-old man with a spinal cord transection at C5 level, blood pressure fell from 110 to $75 \mathrm{~mm}$ after some munutes of Fluothane anaesthesia, severe respiratory depression was also present Substitution with ether brought rapid improvement, with increased respyratory amplitude and a rise in blood pressure to $110 \mathrm{~mm}$. Hg Resumption of Fluothane anaesthesia after one hour again produced circulatory and respiratory depression.

A very obese 65-year-old female patient, admitted to hospital following a fall (probably preceded by a fainting attack), developed auricular fibrillation following induction with Fluothane anaesthesia This patient was hypertensive (B P. 210/110) and showed considerable drowsiness after air ventriculography A subdural haematoma was diagnosed and evacuated without incident Anaesthesia for this operation was induced by thiopental $500 \mathrm{mg}$, Anectine $50 \mathrm{mg}$, followed by nitrous oxide oxygen ether, ether was replaced by Fluothane on transfer to the operating room Hypotension was easily induced by Fluothane, but was readily reversed by discontinuing the volatile supplement for short perıods Tachycardıa up to 130 per minute was observed during and after this operation

Seizures subsequently developed and the patient was unconscious when brought to the operating room for a second craniotomy two days after the first operation While thiosental $(275 \mathrm{mg}$ ) was being given the patient had a short seizure After relaxant and intu sation systolıc blood pressure was $130 \mathrm{~mm}$ (preoperatively $180 \mathrm{~mm}$.) Administration of Fluothane and oxygen by closed circuit (Heidbrink) for approximately two minutes produced systolic 
hypotension to below $60 \mathrm{~mm}$ This was not immediately treated with vasopressors, the view being taken that a satisfactory level of blood pressure would be regamed on discontinuing Fluothane This expectation was not realized, and a delay of five to ten minutes occurred before a blood pressure above $100 \mathrm{~mm}$ systolic was achieved by mfusion of neosynephrine $(20 \mathrm{mg} / 500 \mathrm{ml}$ ). Heart rate was now very fast and irregular The operation was started, electrocardiographic tracings showing rapid auricular fibrillation (Fig 2A)
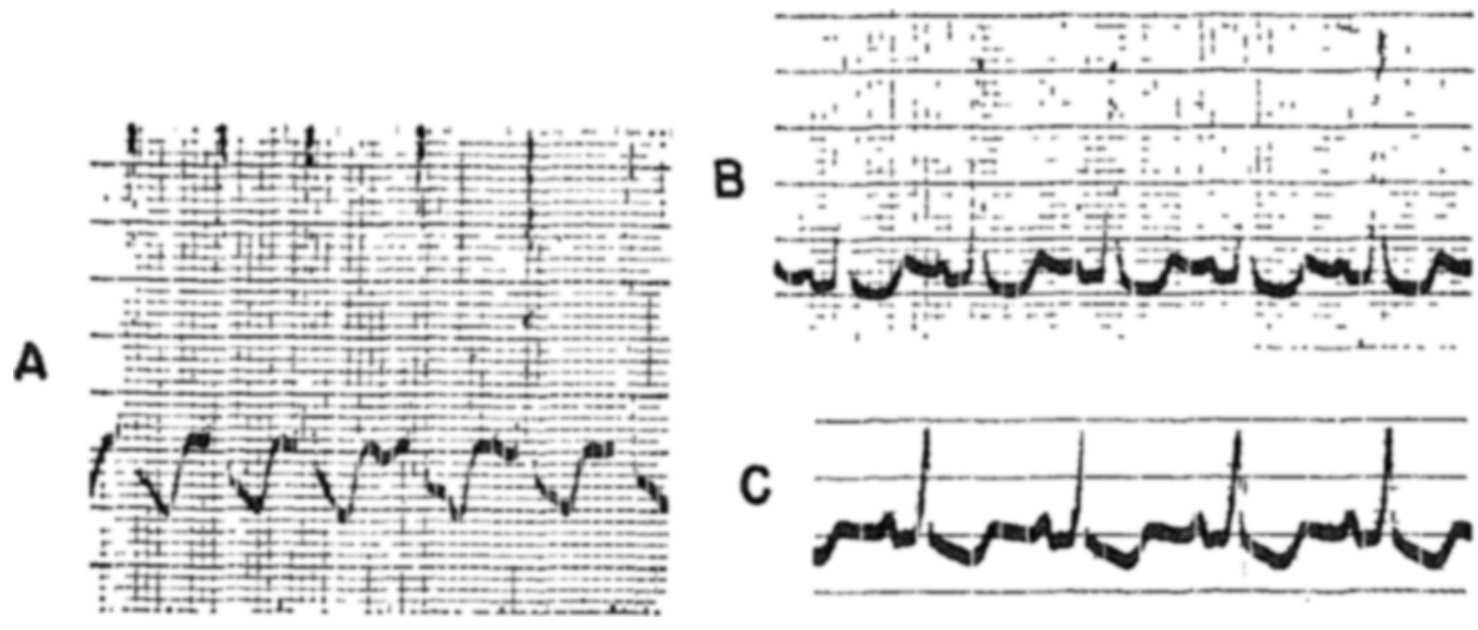

Frgure 2. A, during operation-auncular fibrllation, B, after operation-supraventricular tachycardia, C, first postoperative day-changes in $T$ wave and $S T$ segment.

Blood pressure was maintained throughout operation at $100-140 \mathrm{~mm}$, neosynephnne was no longer required after a total dose of $10 \mathrm{mg}$ injected over 30 minutes Oubaine $(045 \mathrm{mg}$.) was given in divided doses in an unsuccessful attempt to reduce heart rate which persisted throughout at 160 per minute

At the end of operation, after anaesthesia lasting three hows, systolic blood pressure was $120 \mathrm{~mm}$, heart rate 160 . An electrocardiogram 50 minutes after operation showed a sinus rhythm of 140 per munute (Fig 2B) The patient remaned unconscious although reacting, digitalisation maintained heart rate at about 110 per minute On the first postoperative day changes in the $T$ wave and $S T$ segment were apparent ( $F_{1} g$ 2C), hypertension persisted at levels up to $220 / 120 \mathrm{~mm}$ Blood pressure began falling on the fifth postoperative day and death occurred six days after the second operation

Autopsy report demonstrated the following pathological changes in this patient an extradural haematoma in the posterior fossa, a basal skull fracture related to the left transverse sinus, multiple left pulmonary infarcts of undetermined origin, hypertensive arteriosclerotic disease with hypertrophy of the left side of the heart

A healthy male patient, 57 years of age, was induced normally with thiopental $400 \mathrm{mg}$ and succinylcholıne $40 \mathrm{mg}$, followed by light endotracheal Fluothane anaesthesia during posturing in the face down position for exploration of a cervical cord tumour The electrocardıographic pattern was normal ( $F \mathrm{~g}$ BA) The few minutes required for transfer to the operating room permitted lightening of anaesthesia, as the surgenn was injecting local anaesthetic (with added adrenaline), administration of 15 per cent Fluothane in 50 per cent nitrous oxide-oxygen falled to establish a satisfactory plane of andesthesia, dislodgement of the mouth gag and compression of the endotracheal tube by the patient's gums resulted in moderate airway obstruction Electrocardiographic monitoring, resumed in the operating room, withın two minutes of local injection revealed ventricular extrasystoles (Fig. 3B)

Ten minutes following injection of local (with added adrenaline) and after relief of the airway obstruction, the tracing demonstrated multıfocal ventricular extrasystoles (Fig. 3C) Systolic blood pressure was in the range 120-140 $\mathrm{mm} \mathrm{Hg}$ Surgery commenced and Fluothane 

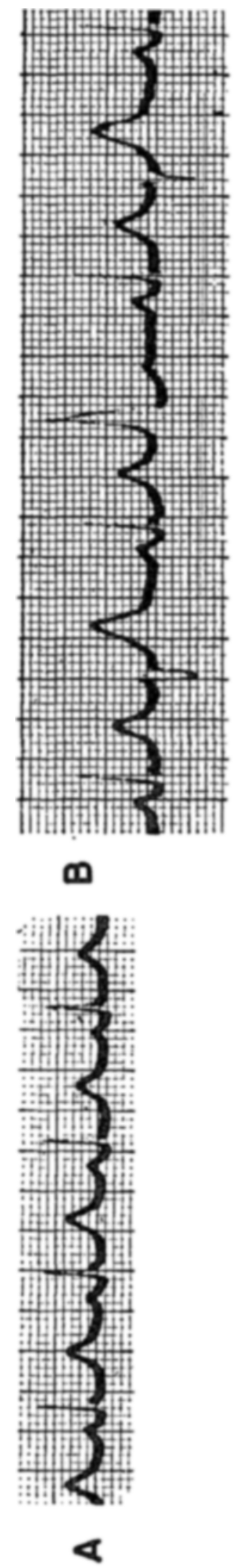
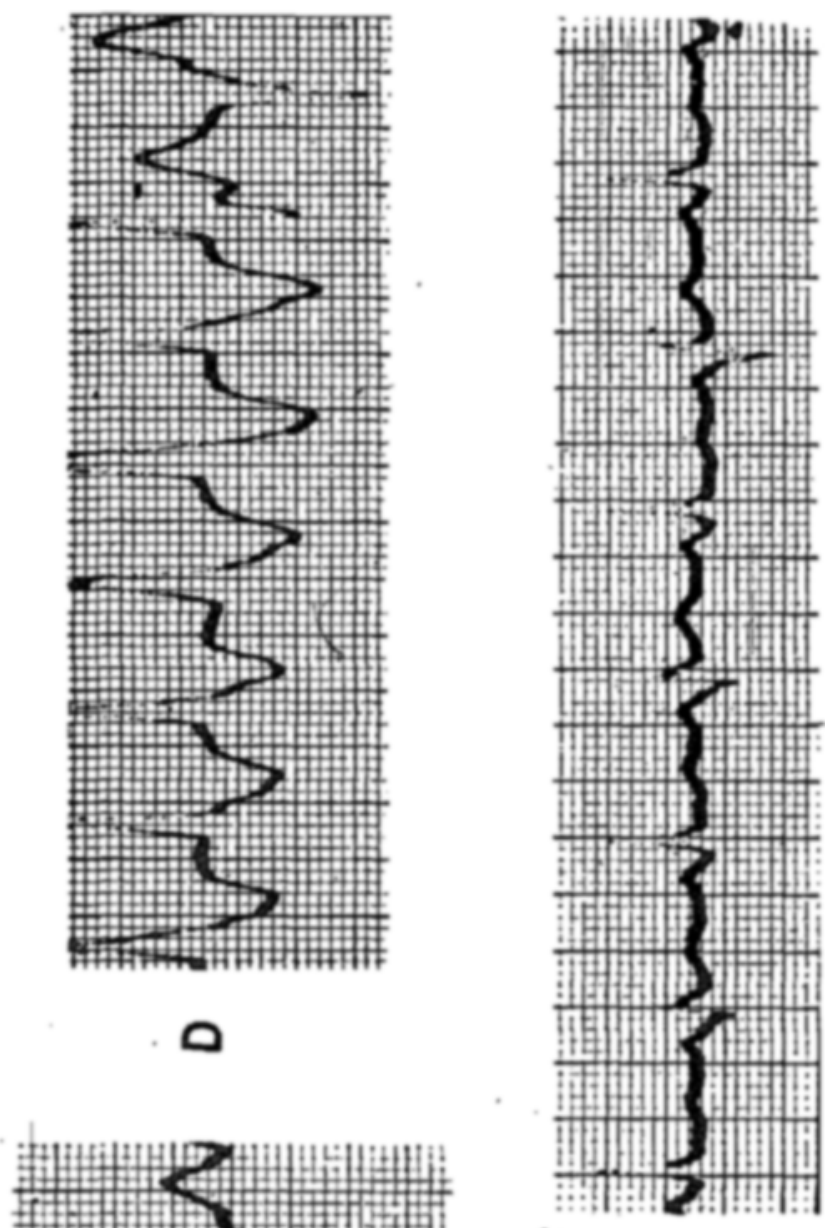

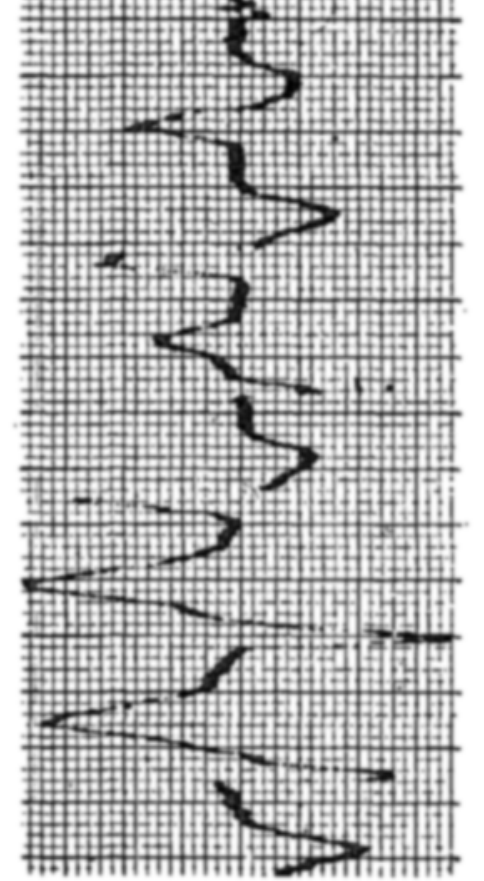

0

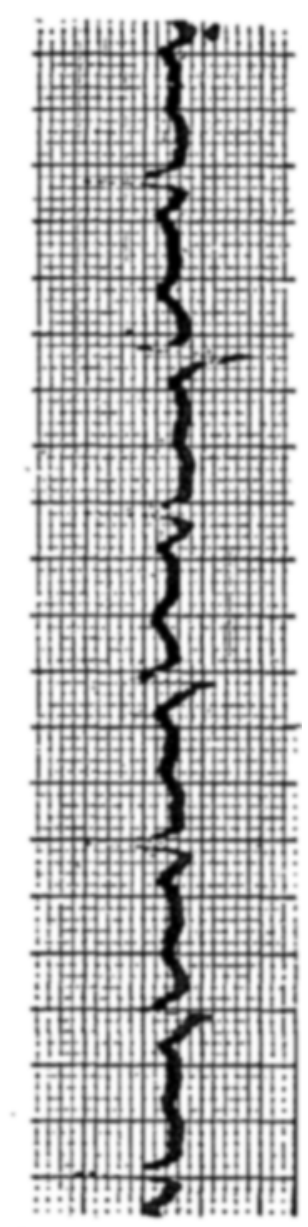

兽总

E

(1) [a

莞

号

충

ॠ

牙索

율

苋志

$\rightarrow>$ 늠

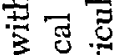

월

记

ज व

\%

틀으를

马

要

出

恶

욤

820

舟

…

-

एँ

吾索

者

$\rightarrow$ 这

$\infty$

昜虽

है छ

5

뎔

冚的

छ

I

5을

함

冚

$\Rightarrow$ ․ㅡ

ㄴ.

氜焉

से

‥

놀

5

$\stackrel{0}{\circ}$

U 

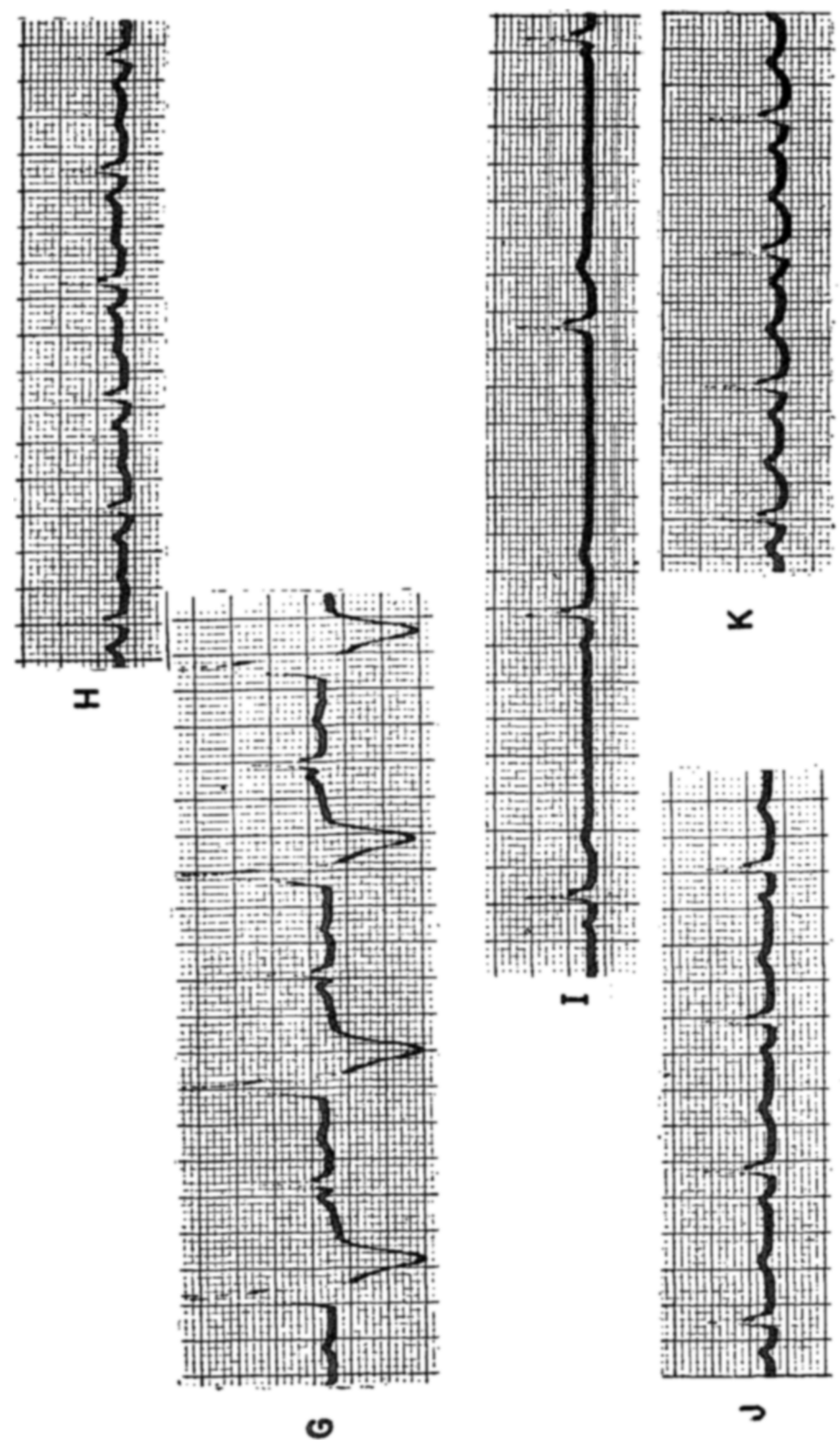

专总 ज्ञ 总 这 焉 bo. D 跑兽 过 胥 刃 . a 要 I 造点 怘心
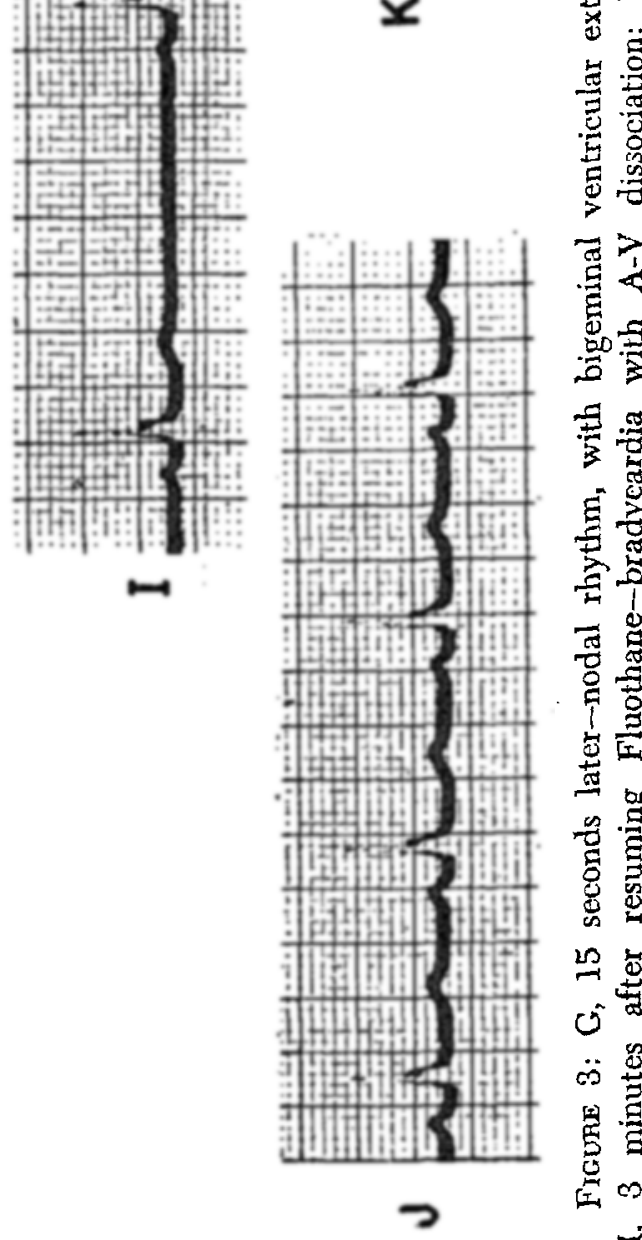

焉

象

齐

焉

E

点

告

可

焉

곤

蛋

g

总总

10 옹

式

$\ddot{g} \mathscr{8}$

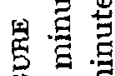

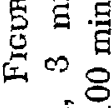


was contunued for a further period of 40 minutes, during which time frequent bursts of ventricular extrasystoles were observed. Fluothane was discontınued 55 minutes after the injection of local, when the tracing stll showed gross irregularities and tachycardia (Fig. 3D). Ether was given (via the Marrett vaporizer), and durng the next few minutes cardiac rhythm gradually became normal. Sinus rhythm was establıshed seven minutes after changing to ether anaesthesia (F.g 3E). Ether was discontınued and Fluothane again administered in a concentration of e.pproximately 1 per cent. One minute, thirty seconds later, interpolated extrasystoles appeared (Fig 3F) Fifteen seconds later a bigeminal rhythm became established in which nodal rhythm was coupled with ventricular extrasystoles (Fig. 3G). Fluothane was stopped and ether anaesthesia resumed, two minutes later sinus rhythm (rate 96 per minute) reappeared ( $F$ ig. $3 \mathrm{H}$ ) Fluothane was again administered, two hours and twenty-five minutes after local injection Three minutes later there was pronounced bradycardia (rate 38 per minute) with A-V dissociation (Fig 3I). Fluothane was discontinued and ether anaesthesia resumed. Two minutes later sinus rhythm (rate 72 per minute) was agan established (Fig 3J) Fluothane was restarted, blood pressure, which had been maintained throughout the penod of arrhythmia at $110-150 \mathrm{~mm} \mathrm{Hg}$, now showed a sudden fall to $85 \mathrm{~mm}$. $\mathrm{Hg}$ which lasted less than five minutes Fluothane was then contnued for the last hundred minutes of operation without further arrhythmia or hypotension. Electrocardiographic tracings at the close of operation ( $F_{1 g} 3 \mathrm{~K}$ ) show sinus rhythm (rate 82 per minute).

\section{ELECTROCARDIOGRAPHY}

Electrocardiographic records were obtained during 31 administrations of Fluothane. In addition to the patient previously mentioned who had auricular fibrillation, changes were observed during 15 administrations on 14 patients. Patterns observed in twelve patients during Fluothane anaesthesia, and apparently

TABLE IX

Electrocardiographic Changes during Fluothane

\begin{tabular}{lcc}
\hline & $\begin{array}{c}\text { Fluothane } \\
\text { (apparently unrelated } \\
\text { to adrenaline) }\end{array}$ & $\begin{array}{c}\text { Fluothane and adrenaline } \\
\text { (within } 30 \text { minutes of } \\
\text { injection of adrenaline) }\end{array}$ \\
\hline I Changes in rhythm & 1 & 1 \\
Sinus tachycardia & 1 & - \\
Sinus bradycardia & 2 & 1 \\
Nodal rhythm & 1 & - \\
Auricular fibrillation & 2 & 3 \\
Shifting pacemaker & 2 & 1 \\
A-V dissociation & 1 & - \\
Extrasystoles & & \\
Supraventricular & - & 2 \\
Ventricular & 1 & - \\
$\quad$ Isolated & - & 2 \\
Interpolated & - & 1 \\
$\quad$ Bigeminal rhythm & - & 1 \\
$\quad$ Mnultifocal & - & 2 \\
Vetricular tachycardia & - & 4 \\
II Depression of & - & 4 \\
$P$ wave & & \\
ST segment & &
\end{tabular}


A
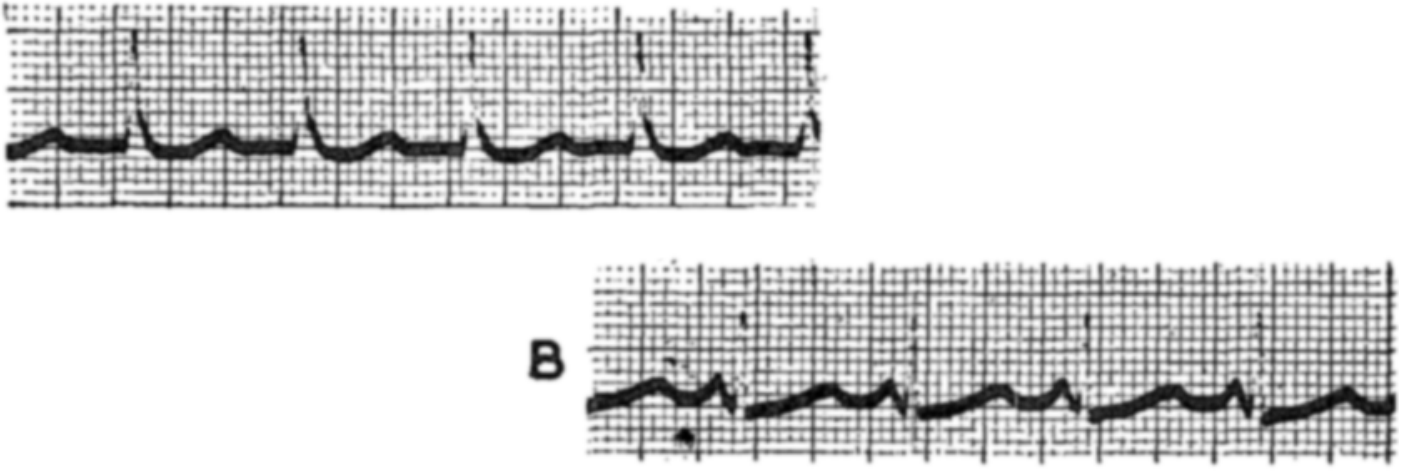

C

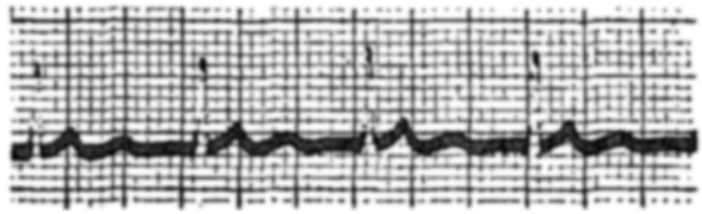

FIgure 4: A, nodal rhythm; B, 15 seconds later-shifting pacemaker; C, 5 minutes latershifting pacemaker $-P$ wave between $Q R S$ complex and $T$ wave.
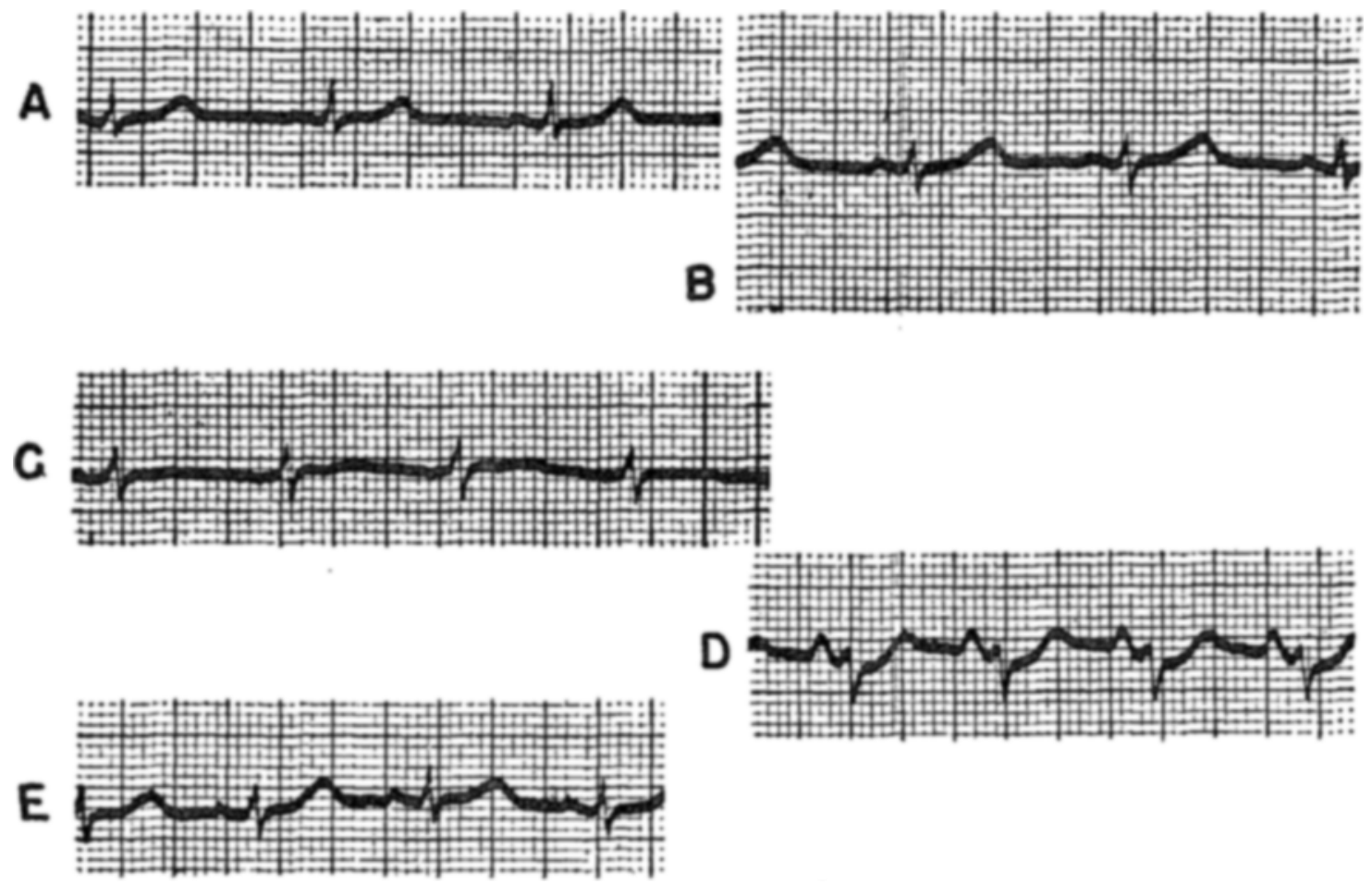

Figure 5 (all lead 2); A, before induction; B, following thiopertal induction and 30 minutes nitrous oxide-Fluothane anaesthesia; $C, 2$ minutes after adrenaline injected with local- $P$ and $T$ wave depression; $D, 5$ minutes after adrenaline- $P$ and $T$ again upright, but $R$ wave decreased in amplitude and $S T$ segment depressed; E, 15 minutes later-return to pre-adrenaline tracing. 

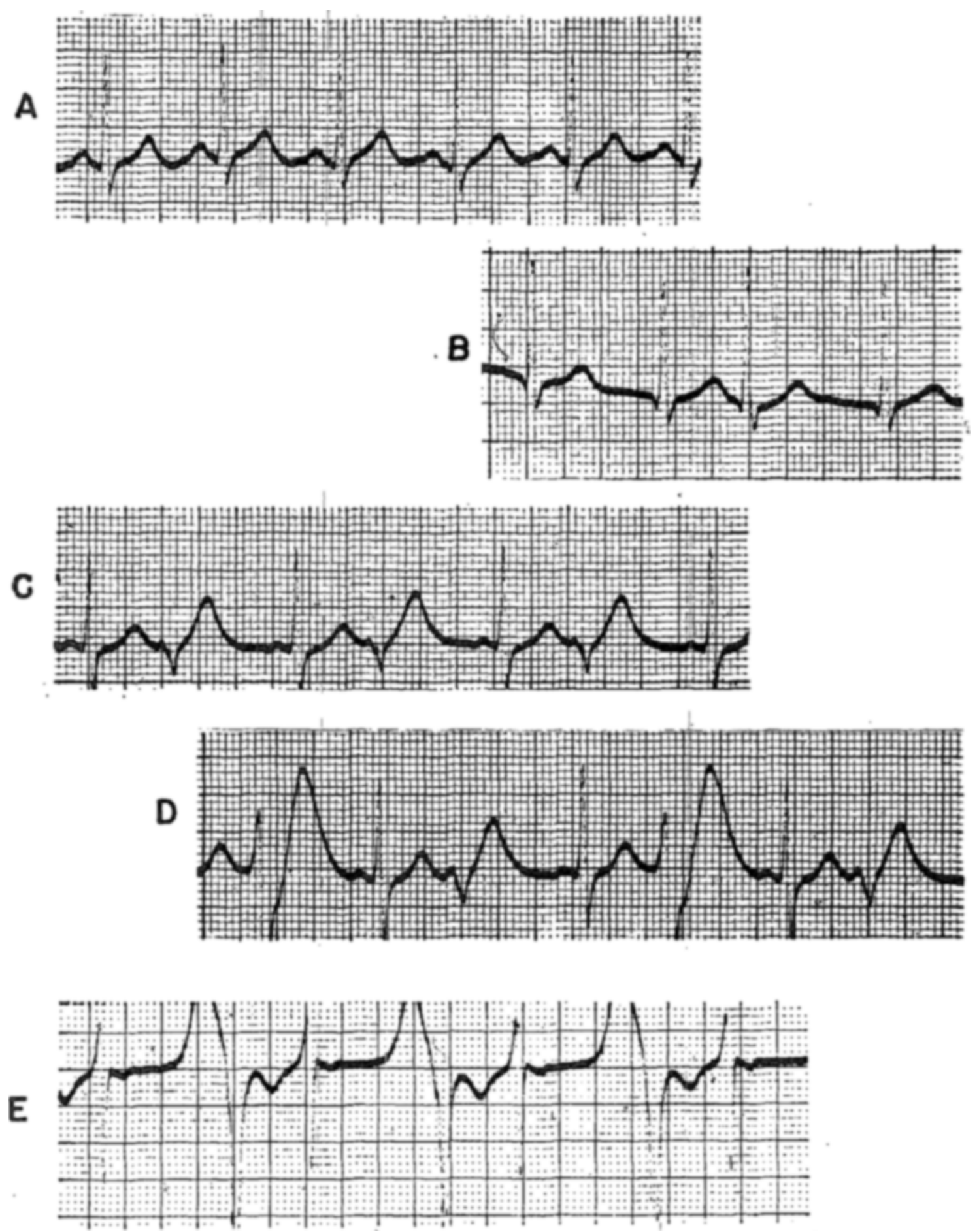

Figure 6: A, after induction-sinus rhythm; B, later-supraventricular extrasystole; C, 2 minutes after injection of local anaesthetic containing adrenaline-pulsus bigeminus; $D, 10$ minutes after injection-bigeminal rhythm with 2 alternating ventricular foci; E, 12 minutes after injection-bigeminal rhythm with single ventricular focus. 
unrelated in time to the injection of adrenaline, are summarized in Table IX. A characteristic tracing demonstratng nodal rhythm with shifting pacemaker is illustrated in Figure 4.

The amount of 1 -adrenaline (free base) added to $125 \mathrm{ml}$. of $1 / 1500$ Nupercaine was 500 microg.; most or all of this volume of solution was injected by the surgeon. Results obtained by the fluormetric estimation of adrenaline in peripheral venous plasma, withdrawn from three patients ten to fifteen minutes after injection of local, are given in Table $\mathrm{X}$.

TABLE $X$

Adrenaline in Peripheral Venous Plasma after Subcutaneous Injection

\begin{tabular}{cccc}
\hline \hline $\begin{array}{c}\text { Before } \\
\text { injection }\end{array}$ & $\begin{array}{c}10 \text { min after } \\
\text { injection } \\
\text { (microg per litre) }\end{array}$ & $\begin{array}{c}45 \text { min after } \\
\text { injection }\end{array}$ \\
\hline 1 & & 039 & \\
2 & 011 & 082 & 015 \\
3 & 021 & 067 & 015 \\
\hline
\end{tabular}

Figure 5 traces the changes in cardiac conduction which occurred following the injection of local anaesthetic containing adrenalme. Figure 6 illustrates the changes observed in one patient, at a time when a definte increase in the circulating adrenaline level was demonstrable.

\section{Discussion}

From this small series of patients subjected to Fluothane anaesthesia of light or moderate depth, several advantages which are difficult to dispute can be cited for the use of Fluothane in the anaesthetic management of the neurosurgical patient. These advantages are: swift, smooth induction; rapid emergence from anaesthesia; absence of respiratory tract irritation, with the attendant advantages of freedom from increases in cerebro-venous and cerebro-spinal fluid pressures; absence of explosive properties.

The smoothness and rapidity of induction and elimination of Fluothane invite superficial comparison with cyclopropane; however, the action of Fluothane on the peripheral circulation more closely resembles that of chloroform. The latter comparison is somewhat unfavourable, however, when it is remembered that the degree of hypotension during chloroform anaesthesia is usually proportional to depth of anaesthesia; with Fluothane this may not be the case. Hypotension is to be expected during Fluothane anaesthesia, it can occur with concentrations as low as 1 per cent, it frequently occurs in hypertensive patients; it may be difficult to control in the poor-risk patient, in certain patıents hypotension may occur before a steady state of anaesthesia is attained.

There is little doubt that the occurrence of auricular fibrullation in one patient was closely related to existing hypotension of several minutes duration. It is 
reasonable also to emphessize the danger of employing closed circuit anaesthesia with Fluothane unless vaporization can be accurately controlled independently of respiration.

At the levels of general anaesthesia employed for neurosurgery, distinctive changes in heart rate have not accompanied variations in blood pressure.

The duration of the operative procedures reported in this series provides a severe test of liver function; considerable increases in bromsulphalein retention occurred and have been attributed to Fluothane by other workers (5); but simillar increases may accompany the administration of other anaesthetic agents, apart from the accepted effects of chloroform (8). In this series there was no clinical evidence of postoperative hepatic disturbance.

It appears, from the data obtamed, that the cardiac effects of Fluothane do not greatly differ from those reported to occur during other forms of general anaesthesia (9) The effect on the heart of ùp to 500 microg. of adrenaline injected subcutaneously in conjunction with local analgesics must depend on the degree of absorption in unit tume. Three patients in this series showed adrenaline levels within the range 0 39-0.82 microg. per litre of peripheral venous plasma 10-15 minutes after injection.

Although an extreme degree of accuracy cannot be claimed for the method of analysis employed, it appears from this that a definite increase in the circulating level of adrenaline is demonstrable following subcutaneous injection during surgical operations. Adrenalıne levels below 1 microg per litre are well within the range of values found in man and dogs during insulin hypoglycaemia (10) and during haemorrhagic shock in dogs (6).

In the laboratory animal expenmental ventricular fibrillation is commonly induced by the intravenous injection of $10-20$ microg. $/ \mathrm{kg}$. of adrenaline, which must lead to precipitous increases in the plasma concentration of adrenaline to figures many times higher than those estimated in these three patients. Nevertheless, one of these patients showed, in sequence, supraventricular extrasystoles, pulsus bigeminus, and a multifocal bigemmal rhythm, within fifteen minutes of local injection, when the peripheral venous plasma concentration of adrenaline had risen to 082 microg. per litre from a pre-injection level of 0.11 microg.

Although three other patients showed ventricular extrasystoles after the injection of adrenaline, only one of these demonstrated recurring ectopic ventricular contractions.

From this limited evidence, it appears that the subcutaneous injection of adrenaline during uncomplicated Fluothane anaesthesia in man may be hazardous. The appearance in one patient of multifocal ventricular extrasystoles emphasizes the potentially dangerous situation which arises when even a moderate degree of anoxia occurs during Fluothane anaesthesia, nor can the possible role of injected adrenaline in this patient be underestimated. Further data is required.

The use of Fluothane can be recommended unreservedly for diagnostic radiological procedures, a field in which this new agent appears to be superior to trichlorethylene.

The difficulty presented by hypotension induced by Fluothane may be overcome by more comprehensive experience, but peripheral circulatory depression is 
the most serious impediment to unconditional acceptance of Fluothane at this tume If hypotension can be utlized and controlled with the ard of carefully administered vasopressor drugs, the potentialities of Fluothane in neurosuigical anaesthesia increase.

\section{SUMMARY}

The volatile anaesthetic agent, Fluothane, has been employed for 108 neurosuigical procedures

The non-irritant, non-explosive properties of Fluothane, together with a desirable flexibility in action, render it a potentally valuable agent for the anaesthetic management of the neurosurgical patient

A serious disadvantage of Fluothane deives from ts hypotensive action, which may appear before an adequate level of anaesthesia has been attained

There is electrocardıographic evidence that the combination of Fluothane and subcutaneously mjected adrenaline is a potential hazard in man.

Tests of liver function after prolonged operations reveal definite abnormality, but this may not be greater than it would be with other anaesthetic agents administered and studied under similar conditions

Fluothane deserves continued investigation as a promising new agent for major neurosurgical procedures At the present time, its use can be particularly recommended for neuro-radiological investugations under general anaesthesia

\section{ACKNOWLEDGMENTS}

Many have aided in this study, the authors would like especially to express their gratitude to Doctors J A. Shanks, A J Johnson and Ivan Beck for therr clinical advice, and to their residents, Doctors I Hildebrand and E. Osmolskı for technical help

This study was generously aided by Ayerst, McKenna \& Harrison Limited, without whose support it could not have been accomplished The sympathetic understanding of the Medical Director, Doctor Leighton Smith, has been much appreciated.

\section{RÉSUMÉ}

Nous avons utilısé un agent anesthésique volatle, le Fluothane, au cours de 108 interventions neurochururgicales.

Les propriétés non-ırritantes et non-explosives du Fluothane jointes à une grande manıabilité et à son action rapide en feront peut-être un précreux agent anesthésique en neurochirurgie.

Il a cependant le sérieux désavantage de présenter fréquemment une action hypotensive qui peut apparaître avant même qu'un niveau suffisant d'anesthésie ne soit atteint.

Les tracés électrocardıographıques nous font également soupçonner que l'usage du Fluothane en combinasson avec l'injection sous cutanée d'adrénalıne peut avoir un effet nuisible sur le myocarde. 
Les épreuves de fonction hépatique après des interventions prolongées se sont montrées nettement anormales dans environ un ters des cas, mais ces troubles ne semblent pas être plus sérieux que ceux que produisent d'autres agents anesthésiques administrés et étudiés dans les mêmes conditions.

Les avantages du Fluothane méritent certainement que l'on poursuive plus loin les recherches mass pour le moment son emploı paraît être plus particuliérement indıqué dans l’anesthésie générale au cours des examens neuro-radiologiques

\section{REFERENCES}

1 Raventós, J The Action cf Fluothane A New Volatıle Anaesthetıc Brit J Pharmacol., 11394 (1956)

2 Johnstone, Miciael. The Human Cardiovascular Response to Fluothane Anaesthesia. Brit J Anaesth, $28392(1956)$

3 Bryce-Smith, R \& O'Britn, H D Fluothane A Non-Explosive Volatile Anaesthetıc Agent Brit Med J, 2969 (1956)

4 Stephen, C R, Bourgeois-Gavardin, M, Fablan, L W, Grosskreutz, D C, Dent, S \& Coughlin, J Fluothane A Prelıminary Report Anesthesiology, 18. 174 (1957).

5 Robson, Gordon Personal Communication

6 Millar, R A To be published (1957)

7 Eulen, U S von \& Floding, I Acta physiol Scandinav, 33 Suppl 118, 45 (1955).

8 Waters, $\mathrm{R} M$ Chloroform A Study after 100 Years Madison University of Wisconsin (1951)

9 Johństone, Mrchael Electrocardiography during Anaesthesia Bit J Anaesth, 28 $579(1956)$

10 Millar, R A The Fluorimetric Estimation of Adrenaline in Peripheral Venous Plasma during Insulın Hypoglyzemia J Pharmacol \& Exper Therap 118435 (1956) 